\title{
SOBRE A CAPA
}

\section{"Qriancas"}

Que humanos seremos quando nos destiriamos a acumular o efêmero-?

"Em querendo tudo,

$$
\text { ná suportamos o nada." }
$$

$E$ preenchemos esse vazur

$$
\text { rumi nando, remascando, remoendo. }
$$

$$
\text { Panico, até } \theta \text { desgaste total. }
$$

$$
\text { medo, insónia }
$$

Que excemplos de adultos felizes as criancas estaw absorvendo? E no's, os mais espertos, nos. surpreendemos quando esse vazio í preenchido por coisas, drogas, seitas on quaisquers inibidores

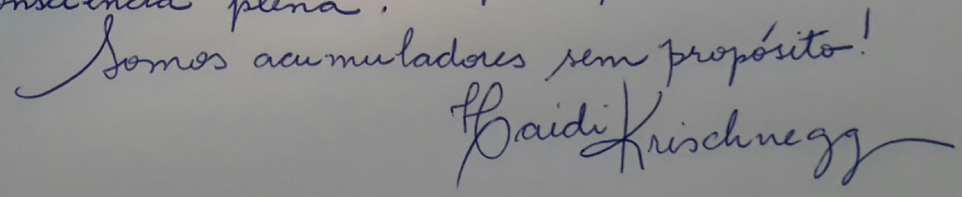


